ppi $201502 Z U 4645$

Esta publicación científica en formato digital es continuidad de la revista impresa ISSN-Versión Impresa 0798-1406 / ISSN-Versión on line 2542-3185Depósito legal pp $197402 Z$ U34
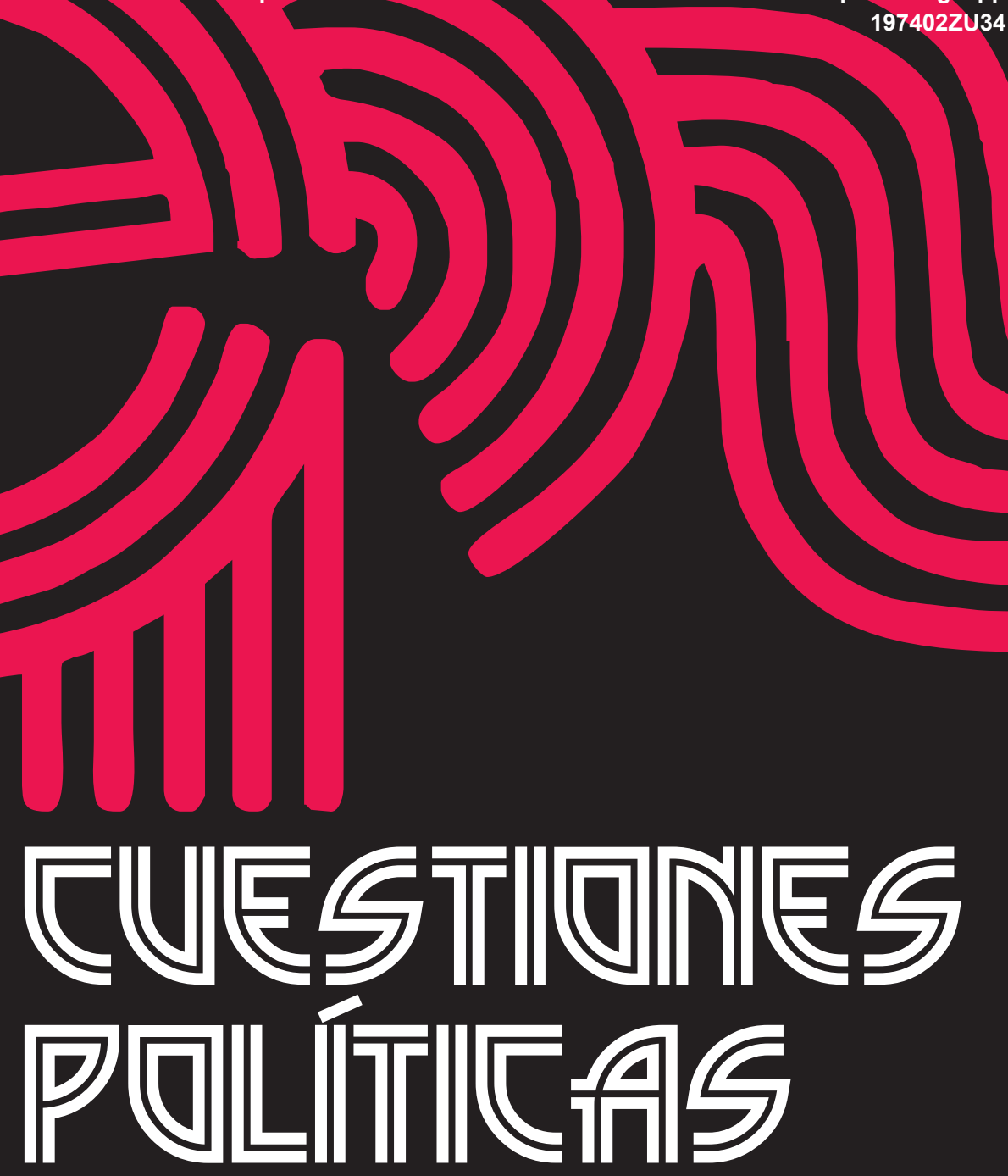

Instituto de Estudios Políticos y Derecho Público "Dr. Humberto J. La Roche" de la Facultad de Ciencias Jurídicas y Políticas de la Universidad del Zulia Maracaibo, Venezuela
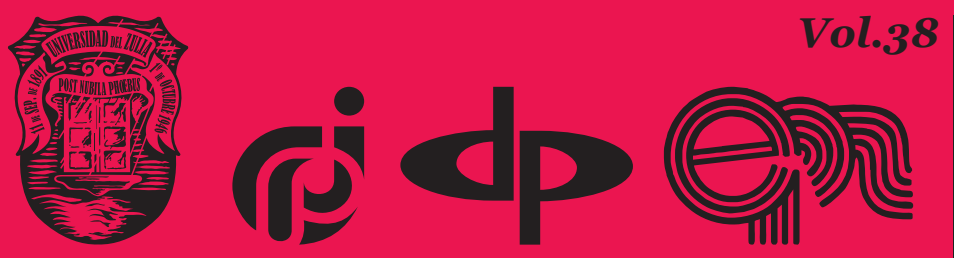

$N^{\circ}$ Especial 2da Parte 2020 


\title{
Legal basis for the interaction between local with state authorities
}

\author{
DOI: https://doi.org/10.46398/cuestpol.382e.09
}

\author{
Jaafar Naser Abdulridha * \\ Salwan jaber hashim ** \\ Evgeny Batirovich Sultanov ***
}

\begin{abstract}
The objective of the article is to analyze the legal basis for interaction between local and state authorities within the framework of the current constitution of the Republic of Iraq. At the methodological level, documentary observation was used. In recent years, after the transition to a new political regime in Iraq in 2003, many issues relating to local administrations and their interaction with state bodies have been identified and enshrined in the Constitution of the Republic of Iraq in 2005. Some of the most serious problems are the lack of a clear organization of relations between government bodies and local governments, the efficiency problems of the various authorities, as well as the lack of flexible solutions in legislation and the Constitution. The need to solve these problems is often manifested at all levels. At the same time, we find no real decisions that do not cause popular discontent in all Iraqi provinces, especially in Basra province. It is concluded that relations between regional and national authorities are mediated by the presence of bureaucracy, financial and administrative corruption administrative and political conflicts between political parties.
\end{abstract}

Keywords: local administration in Iraq; administrative decentralization; state power; Iraqi political reality; federal law.

* Senior Lecturer, Kazan Federal University, (Faculty of law), Al-Basrah University Republic of Iraq, (Constitutional and administrative law). ORCID ID: http://orcid.org/oooo-0oo2-7154-1176. Email: Jaafarna124@mail.r

** Senior Lecturer /Faculty of Law /AL Nahrain University. Ira (International law). ORCID ID: http:// orcid.org/oooo-0o02-4235-2157. Email: sellwan@mail.r

*** Faculty of Law, Kazan Federal University, Kazan, Russia (Constitutional and administrative law). ORCID ID: http://orcid.org/oooo-0002-4170-0172. Email: sultanov2007@yandex.ru 


\section{Base legal para la interacción entre autoridades locales y estatales}

\section{Resumen}

El objetivo del artículo es analizar la base legal para la interacción entre autoridades locales y estatales en el marco de lo que estipula la constitución vigente de la república de Irak. A nivel metodológico se hizo uso de la observación documental. En los últimos años, después de la transición a un nuevo régimen político en Irak en 2003, se han identificado y consagrado en la Constitución de la República de Irak de 2005 muchas cuestiones relativas a las administraciones locales y su interacción con los órganos estatales. Algunos de los problemas más graves son: la falta de una clara organización de las relaciones entre los órganos de gobierno y los gobiernos locales, los problemas de eficiencia de las diversas autoridades, así como la falta de soluciones flexibles en la legislación y en la Constitución. La necesidad de resolver estos problemas se manifiesta muchas veces en todos los niveles. Al mismo tiempo, no encontramos decisiones reales que no causen descontento popular en todas las provincias iraquíes, especialmente en la provincia de Basora. Se concluye que, la relaciones entre las autoridades regionales y nacionales esta mediada por la presencia de burocracia, corrupción financiera y administrativa y conflictos políticos entre partidos políticos.

Palabras clave: administración local en Irak; descentralización administrativa; poder estatal; realidad política iraquí; ley federal.

\section{Introduction}

The issue of the distribution of competencies between local authorities and the state was brought up in the Provincial Coordination Committee, which held its meeting in 2010 with the aim of transferring some powers to the provinces. This is one of the main issues of state policy regarding the development of local self-government in Iraq; it was included in the first amendment to the law about the provinces. The recommendations of the Steering Committee included the need to provide local governments with opportunities and initiatives to create the conditions necessary for the sustainable development of the provinces.

This is done by coordinating work with federal authorities in all areas of service in order to guarantee the rights and freedoms of the local population, as well as improve their living standards (Al-Lamy, 2018). The 
development of local self-government should lead to the creation of an effective and influential system of relations between the population, local authorities, and other state bodies.

The new regime established in Iraq after 2003 guarantees that powers and resources will be fairly distributed between all levels of government; clear and precise foundations and mechanisms of relations will be established between branches of government and the principles of the state will be precisely defined. The responsibility of each level of government in Iraq, whether local or federal, is to equitably distribute the powers and resources needed to develop society and ensure the provision of services to the entire population.

\section{Methods}

The methodological basis of the study consists of general scientific dialectical methods of cognition, scientific methods of analysis and scientific forecasting, synthesis and deduction, system methods, as well as special methods for studying legal phenomena: historical-legal, comparative-legal, structural-functional, etc.

\section{Results and Discussion}

In general, it should be noted that the problem of identifying and distributing powers and their constitutional structure is one of the most important problems limiting the effectiveness of local authorities. As a result, there is a lack of clarity on the local government's strategy for managing local affairs, especially in light of the ambiguity of the administrative decentralization system in Iraq and its connection with all the crises that it faced in exercising its internal jurisdiction.

As a result, the confusion that arises in the activities of officials in an attempt to understand the responsibilities and authorities assigned to them ultimately leads to a dispersal of efforts and the failure of the development process, which became the subject of controversy and political debate and contributed to the emergence of two scenarios. First scenario tends to exist of a centralized power when executive powers are delegated to the state in the interests of its representative at the provincial level. The second scenario protects political actors at the municipal and provincial levels and tends to give real power to local elected councils (Nasruddin, 2009). In this regard, the issue of limiting the powers granted to local authorities and the need to eliminate uncertainties regarding them is raised again. 


\section{4 \\ Jaafar Naser Abdulridha, Salwan jaber hashim y Evgeny Batirovich Sultanov Legal basis for the interaction between local with state authorities}

As concerns empowerment of local authorities, the law on provinces and municipalities contains ambiguity, commonality and inaccurate language. This led to a duplication of powers of local and federal authorities without restriction of interventions (universal freedom): with the assumption that they are doing everything, they are really not able to do anything in a clear and precise form in all their roles together with the federal authorities (Leinen, 2020; Li-Ann, 2004).

If the principle of local independence is practiced as self-government in accordance with own laws, then the independence of local provincial and municipal authorities does not extend to the legislative function, i.e. legislation relating to them, and is primarily aimed at organizing a local community. Independence is limited to executive functions at the local level and is referred to as partial independence or relative freedom; the latter should be carried out within the framework of legal norms specified in the Constitution or in state laws (Homel and Fuller, 2015)

Thus, the principle of local independence was defined, on the one hand, as the right to choose or show initiative, and on the other, to give preference to the rights of local authorities, seeking even to oppose state authorities.

Independence here is one of the foundations of administrative decentralization, which at the same time aims to give some freedom to local authorities in the process of carrying out their own activities (Khani Khaschekchi, 2010). Therefore, we believe that local authorities are independent if they have the power to do so; otherwise they are not free or independent.

The issue of independence of local communities is addressed in legal documents. Here the state grants legal status, autonomy, and independence them and even their constituents, as well as those who manage them. Communities exist regardless of changing or replacing local councils. Local authorities always have freedom of initiative and action; in this regard, the central government is not able to replace them, with the exception of cases provided by law (Nasruddin, 2009).

This is confirmed by Professor Nasruddin in his analysis of Art. 44 of the law on provinces. He admits that the legislator has established a common framework for interference in the affairs of municipalities and provinces, while providing them with freedom of activity and legal capacity. This indicates that the legislator has not established a criterion of exclusive jurisdiction in order to indicate the independence of local authorities (Leinen, 2020). Accordingly, a number of legal provisions confirm the independence of these bodies in managing the development of local areas and this is evidenced by the powers vested in them by law.

Based on the foregoing, it makes sense to say that the state is able to choose between what it yields in favour of the local authorities, and what it retains. 
Compared with the constitutional framework for the issue of local community independence, the legal framework has identified and detailed the manifestations of the independence of local community bodies in terms of their functions and decision-making ability, starting with the law on municipalities. The Law on Municipalities and Provinces contains the general principle of freedom of local authorities, which embodies the meaning of freedom and independence.

The municipal charters state that municipal authorities make appropriate decisions within their competence without prior notice to state authorities, without government intervention in order to change the decisions or amend them. Supervision permitted by law should not be carried out in a way that is not consistent with the concept of decentralization, but should be within the framework of the provisions of the above Charters (Art. 34 of the Federal Law No. 165 of on Municipal Management, 1964).

It is obvious to us that at that time, Iraqi lawmakers were fully convinced of the need to provide municipalities with decision-making independence and freedom, which they would consider appropriate at the regional level, by including an appropriate article in which legal control was allowed to ensure compliance with the concept and elements of decentralization. The Law about Provinces also provides for a decentralized government in provinces with all the powers necessary to carry out their tasks and to be a decentralized unit, like a municipality. Thus, the local council takes decisions and measures that it considers appropriate and a government representative intervenes only if decisions are required to comply with the law.

In addition to the aforementioned Charter, the legal basis for the independence or freedom of local authorities was enshrined in municipal law of 1964 (Art. 43. Law No. (165) and the Law about Provinces of 1969 (Art. 86 of the Federal Law No. 159, 1969). In our opinion, this independence is expressed through the creation of an elected deliberative council (Municipal People's Assembly and the State Council of the Public) and the implementation of the duties assigned to them by law. In the Law about Provinces No. 21 of 2008, the term "independence" is used to refer to both municipalities and provinces.

Local communities enjoy legal independence that distinguishes them from central administration and recognizes their special interests in their territories, which is a manifestation of their freedom. In addition, Iraqi lawmakers link the independence of local authorities with their ability to solve local problems, stating: "The local council should ensure the creation of appropriate conditions for the development of local initiatives aimed at encouraging citizens to participate in solving their own problems and improving their housing conditions" (Schamel Khadi, 2014: 61). Iraqi lawmakers have expanded the powers and responsibilities of elected local councils through their right to make decisions regarding local issues. 
136 Jaafar Naser Abdulridha, Salwan jaber hashim y Evgeny Batirovich Sultanov

In stating the foregoing, it should be noted that if the basis for the creation of local bodies is the law issued by the parliament in accordance with the territorial organization of the country, then the laws governing these areas are the basis for their independence and freedom in exercising their powers in all areas. Thus, we believe that local authorities have complete freedom of intervention and the timing of the intervention in accordance with their capabilities and potential.

For Iraq, the model of interaction between federal and local authorities has some features of the "Asian model" (the "Asian model" is characterized by centralism of the executive branch, in which the president puts his governors at the head of local administrations called upon to conduct presidential policies on the ground). The partnership model is practically unsuitable here. In our opinion, the most suitable model capable of harmonizing relations between central and local authorities is the aforementioned model, which is based on the concept of interdependence. According to this conception, the central authorities of the republic could build their relations with local authorities, leading the differentiation of these relations to dependence on the specific field of activity, and providing full independence to the municipal authorities within their own authority and, of course, within the framework of the law, while establishing effective control over the implementation of their activities in the field of delegated authority.

The issue of the transfer of authority is one of the issues raised in connection with the emergence of many legal and political problems. The reason is the establishment of a democratic political regime after 2003 as a result of the actions of the coalition Provisional Government formed after the occupation of Iraq by an international coalition led by the United States of America. The problem is the distribution of responsibilities based on ideological, national, ethnic, and religious affiliations.

On April 27, 2003, an Interim Governing Council consisting of 20 members was formed. Subsequently, the 2004 Law on Transitional Government was passed; it introduced a democratic republican federal parliamentary system based on political pluralism. The goal is to incorporate the relevant principles into the 2005 Iraqi Permanent Constitution and facilitate the distribution of powers between the federal government and the Kurdistan government, as well as local administrations existing in provinces outside the autonomy (Khaider Adam, 2006).

However, it is noteworthy that the process of delegation of authority is complex. The reason is the duplication of these powers between the federal authorities (legislative - executive - judicial) and local authorities in relation to joint and exclusive powers. This takes place both in the Constitution and in existing laws or in laws to be adopted. An example is the bill on the Main Directorate for autonomies and provinces that are not part of 
autonomies, prepared by the federal government for transfer to the Council of Representatives of Iraq with the goal of finalizing legislation regarding the organization of relations and the distribution of powers between the centre and the parties.

The plurality of decision centres and partially overlapping powers due to the lack of clarity within the boundaries of the power itself have made the nature of the approach and the method used in political decision-making mechanisms complex and confusing in addition to the plurality of powers and disagreement on the ultimate limits of exceptional authority granted to the federal government. Partial coincidence of some of them is expressed in the joint powers of the centre and local administrations in accordance with the Constitution. In the event of a conflict between the powers of local authorities and the federal government, priority shall be given to the latter. And in the event of contradictions and conflicts between federal law and the laws of local administrations, if they do not fall under the exclusive powers of the federal authorities (Khaider Adam, 2006).

Nevertheless, the issue of transferring powers to local administrations remained controversial and had many interpretations from all political parties, which reflect in some cases a lack of understanding as to the limits of exercising powers, and in others, a complete failure to comply with constitutional and legal texts on this topic. The distribution of powers means a lack of power among those who manage at the expense of other institutional structures available in the state, using a decentralization system in the management of state institutions with the aim of interaction between local authorities and federal authorities in the process of implementing public policy. Dr. Abdul Kader Khamid Rashid emphasizes that the fragmentation of power and the distribution of power according to the principle of decentralization is an essential element of healthy societies open to democracy. It is a mechanism by which freedom is achieved and maintained, which requires a civilized national identity with the creation of a strong government that guarantees the maintenance of order. In parallel, there is a separation of powers on the basis of the existence of a sociopolitical institutional agreement that distributes power among all political parties in accordance with the principles of legal sovereignty.

\section{Summary}

The distribution of powers should be based on the following principles (Khaider Adam, 2006):

1. Determination of the terms of reference for the central government and local authorities by exclusion; determination for local 
administrations in the provinces of the competencies carried out within the powers of local officials.

2. The exercise of the powers of the federal government will facilitate the activities of local administrations within the constitutional and legislative framework with the aim of applying a distinctive new approach in a decentralized administration.

3. In the event of a conflict of opinion regarding powers between the federal government and local administrations, firstly, it is necessary to resolve the conflict regarding powers, so that other issues that do not cause a conflict of powers remain the prerogative of local administrations in the provinces. Art. 110 of the Constitution states that "powers not provided for by federal authorities belong to autonomies and provinces that are not part of autonomies, or joint powers of the federal government and autonomies are determined, where priority is given to the laws of autonomies and provinces that are not part of autonomies, in a case of disagreement between them."

This is another legal problem, which consists in expanding the powers of local administrations to the detriment of the central federal authorities. It is especially important to consider that the priority of local authorities with this form and such a mechanism weakens the authority of the centre. As a result of this, on the one hand, the centre does not have the ability to manage the necessary and urgent development projects in the country, and on the other hand, there are contradictions and other legal and constitutional problems in the process of following the instructions issued by local administrations in implementing infrastructure projects in their provinces; as we see, the instructions overlap centre management (federal government) practices (Mohammed Salakh, 2009; Al-Harajih, 2014).

\section{Conclusion}

In the light of such overlappings and the lack of understanding the boundaries of the development and implementation of state policy between federal and local authorities in accordance with their legal powers approved by each of the parties, we are witnessing an increase in the number of failures and a decrease in the degree of completion of planned projects. The reason is the presence of bureaucracy, financial and administrative corruption, political conflicts between the parties and other issues that impede the universal satisfaction of the growing needs of citizens.

The key to effective interaction between local authorities and public authorities is a specific and accurate definition of the legal nature of both representative and executive-administrative bodies of local self- 
government. Therefore, it is necessary to develop these issues in detail in future legislative acts. In addition, it is necessary to limit the state legislatively concerning the exercise of its power functions by public authority of another kind: the power of society and of local communities. The public nature of the authority of local governments does not exclude, but implies the possibility of exercising by local governments the certain state powers delegated exclusively by law according to Article 115 of the Constitution of the Republic of Iraq.

In practice, it is often difficult to draw a clear line between self-government (issues of local importance) and public administration (separate state powers). The Constitution of the Republic of Iraq does not provide clear criteria for the separation of powers between local self-government and state power; therefore, this gap should be filled at the legislative level.

\section{Acknowledgements}

The work is performed according to the Russian Government Program of Competitive Growth of Kazan Federal University.

\section{Bibliographic References}

AL-HARAJIH, A.K. 2014. "The Problem of Creating a Federal System in Iraq" In: Journal of Law. No. 7, pp. 34-56.

AL-LAMY, Andre. 2018. Read about provincial councils in the second amendment to the law. Available online. In: https://www.marafea.org. Consultation date: 04/11/2019.

ARTICLE 86 OF THE FEDERAL LAW NO. 159. 1969, "On the Province," Iraq Chronicle. Date of issue: 13-10-1969 Page Number: 1 | Number of Pages: 12 Part Number 2. Iraq, Bagdad.

ARTICLE 34 OF THE FEDERAL LAW NO. 165 OF ON MUNICIPAL MANAGEMENT. 1964. See: Art. 43 of the Law No. (165) ibid. Iraq Chronicle | Date of issue: 22-11-1964 Number of pages: 39 Part number 1. Iraq, Bagdad.

HOMEL, Peter; FULLER, Georgina. 2015. "Understanding the local government role in crime prevention" Trends \& issues in crime and criminal justice no. 505. Canberra: Australian Institute of Criminology. Available online. 
Jaafar Naser Abdulridha, Salwan jaber hashim y Evgeny Batirovich Sultanov
140 Legal basis for the interaction between local with state authorities

In: https://www.aic.gov.au/publications/tandi/tandi505. Consultation date: $15 / 10 / 2019$.

KHAIDER ADAM, A. 2006. "The Federal System and Applicability in Iraq" In: Journal of Law. Vol. 15, No. 36, pp. 54-69.

KHANI KHASCHEKCHI, A. 2010. Administrative Decentralization in Iraq: Concept and Legal Content. The thesis for the degree of the Doctor of Law. Basra, Iraq.

LEINEN, R. 2020. "Striking the right balance: disclosure of third-party funding" In: Oxford University Commonwealth Law Journal. Vol. 20, No. 1, pp. $115-138$.

LI-ANN, T. 2004. "The Death Penalty as Cruel and Inhuman Punishment Before the Singapore High Court? Customary Human Rights Norms, Constitutional Formalism and The Supremacy of Domestic Law in Public Prosecutor V Nguyen Tuong Van" In: Oxford University Commonwealth Law Journal. Vol. 4, No. 2, pp. 213-226.

MOHAMMED SALAKH, N. 2009. "Federalism in the Iraqi Constitution" In: Journal of Law, Baghdad, Iraq. Vol. 36, No. 63, pp. 226-20.

NASRUDDIN, B. 2009. Current trends in local management systems, comparative research. $\mathrm{PhD}$ thesis. Muslim University. Aligarh, India.

SCHAMEL KHADI, M. 2014. Local authorities between independence and control. Study guide. Basra, Iraq. 
Vol.38 NEspecial

Esta revista fue editada en formato digital y publicada en diciembre de 2020, por el Fondo Editorial Serbiluz, Universidad del Zulia. Maracaibo-Venezuela 